Historic, Archive Document

Do not assume content reflects current scientific knowledge, policies, or practices. 



\title{
62.27 DESCRIPTIVE
}

\section{PRICE-LIST OF NURSERY STOCK,}

\section{SIOUX CTTY NURSERY \& SEE⿰E⿱一⿴⿻儿口一寸D CO.}

\author{
SIOUX CITY, IOWA.
}

\section{This PRICE $=$ LIST is Our AGENT.}

\author{
It Promises that you will get
}

Good Stock and Fair Treatment.

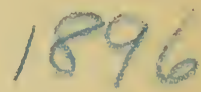

We Guarantee the Fulfillment of this Promise.

This Price List tells you of Fruits, Trees, cte. as they are, and not what they are imagined to be.

In the Best of Times it is hard enougln to pay the high prices asked by Traveling Agents. In these Hard Times it is ont of the question.

Why do you pay Agent's Prices when you positively can get the Very Best Stock of us at One Half and Less the cost. Convinee yourself by examining Our Prices and compare with Agents Prices. It costs 50 to 60 per eent. to sell through agents. We know it for we have tried it. Then, too, when you buy Direct of Us you will get Just What You Order, and if mistakes are made we stand ready to correct them.

TIME OF SHIPMENT-We ean ship from about March 25th to the close of the season. ORDER EARLY. We are certain to be short oll VERY MANY IIINDS of stock before the elose of the season. You had better orcler us to book you for what you want EARLY. FIRST CoMe, FIRST SERved. You ean order stock booked, and pay for it when you want it shipped.

PAYMENT-Our terms are strictly CASH, before shipment, unless parties are favorably knowæ. We refor you to any bank or business man in Sioux City as to our reliability.

CAUTION-Write your name and address plainly. Instruct us whether to ship by FrEIGIIT or EXPREsS.

FREE-We make no charge for Boxing or Drayage.

COMBINED, OR CLUB ORDERS-Our patrons frequently find it to their advantage to order for their neighhors, and in so doing, make a handsome saving by combining their orders! to secure 10, 100 and 1,000 rates; but in order to do this, sneh order must be made by one person and by him divided, otherwise they are prieed als single order's. We trust that the above explanation will induee our Patrons to send as large orders as they cau, thi reby inenefiting themselves and us.

MIXED LOTS-Different kinds may be seleeter to make ny lots of $10,20,50,100,100 ;$, etc., to secure the lower prices, but they must ba of the same age, or size, and from the same class of stock, i. e., all fruit trees, or all grapes, etc.

VARIETIES-IVe wish to eall the attention of our patrons to this very important faet that we are only propagating and offering to our trade the very best and hardiest varieties known. This list is vetvery short. There are many nurseries that are selling at Fancy Prices new varieties that, in nine cases out of ten are valueless. The plaee to test the value of new varieties is in the Nursery not on the Farm.

\section{NURSERY STOCK BY MAIL.}

To aceommorlate our patrons who do not get their mail at railroar towns, and to save expross on small orriers of Roses, Surubs, small Frnits, ete., we have determined to open up a Mail Department, bnt we shall only mail the following kinds of stock, and in orders rmuning from alsont 50 cents to $\$ 2.00$ : Dewherries, liaspl), rries, Blackherries, Curranis Juueberries, Huckleberries, Goosherrics, Strawherries, Rocky Mountain Clucrry, Grapes, Roses, Slumbs, Climbing Plants. Seedling kvergreens. In remittinir don't fail to add to the Prices in the list at the rate of 10 cents for each $\$ 1.01$

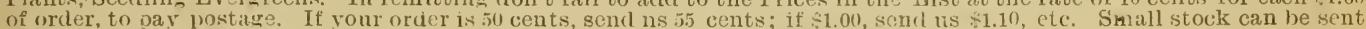
just as safely by Mail as by Express.

\section{FRUIT TREE DEPARTMENT.}

KINDS.

APPLE OR CRAB

CHERRI, PLUM, PEARi or APRICOT,

$\begin{array}{lr}\text { ACE. } & \text { SIZE. } \\ 2 \mathrm{yr} . & 4 \text { to } 5 \mathrm{ft} . \\ 3 \mathrm{yr} . & 5 \text { to } 6 \mathrm{ft} . \\ 2 \mathrm{yr} & 4 \text { to } 5 \mathrm{ft} . \\ & 5 \text { to } 6 \mathrm{ft} .\end{array}$

to $5 \mathrm{ft}$.

to $5 \mathrm{ft}$.
EACH.
15 ets.
20 c.ts.
30 cts.

30 cts.

$\begin{array}{ll}10 & 25 \\ 8100 & 8225 \\ 150 & 32.7 \\ 22.5 & 550\end{array}$

$\begin{array}{ll}225 & 550 \\ 325 & 700\end{array}$
$50 \quad 100$

400

600

1000

1400
78

1) 00

1800
2000 1300 1800 3i) 00 5000

IVe carry in Full Stock the following varicties, but have othor varieties in Small Lots. If the purchasers will leave to us the selection of varietics, we will exereise great care in selecting only those suited to their latitude. We have in APPLE-SUMMER-Duchess, Yellow Transparent, FALL-Wealthy, Snow, Tetosky. WINTER-Ben Davis, Wine Sap, Walbridge, Pewaukee, Haas, Mann, Perry Russett, Talman Sweet, Iowa Blush, R. Janet.

CRAB-SUMMER-Whitney. FALL-Martha, Transcendant, Red and Yellow Siberian, Golden Beauty. WINTER-Hyslop, Soulard, Briar Sweet.

CHERRY-Early Richmond, Olivet, Wragg, Ostheim, Eng. Morello, Large Mont.

PLUM-Wild Goose, Minor, Wolf, Desoto, Weaver, Forest Garden, Pottawattamie, Hawkeye.

PEAR-Keifer's H., LeConte.

Those varieties of Apple, Crab, Cherry, etc. printed in black letters are the best and hardiest, 
Wie give more prominenee this year to Russian Fruits than in former Catalogues. We deseribe and quote oniy the very best, and very hardiest, and you can rely on this stoek being Genuine.

rens.

RUSSIANS.

AGE. SIZE.

SIZE.
3 to $4 \mathrm{ft}$.
t to $5 \mathrm{ft}$.

EACH.

$35 \mathrm{cts}$.

4 to 5 ft.

40 ets.

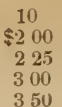
$\$ 400$
500
(6)

50
$\$ 700$
900
1200
1500

100
$\$ 1300$

$2 \mathrm{rr}$.

VARIETIES OF RUSSIAN STOCK.

APPLE-FALL-Longfield, No. 161, Fruit Yellow, very hardy, free from sun-seald, prolifie bearer. LATE FALL-Hi= bernal, No. 378, Hardier than Duchess and just as prolific, fine market variety. LATE WINTER-Repka Malenka, No, 410, fruit yellow, quality excellent.

CHERRY-Vladimer, (250rel) very valuable, large as Montmorener, fruit black, flesh firm, juiey and nearly sweet. Lutovka-fruit large, dark red, pure flavored.

PEAR-Bessemanka-(No. 508) does well to the 4 th parallel, fruit medium in size, nearly seedless, flesh tender and juicy Plant on dry soil, and deep. Gakovska-(No. 347) This can be grown on dry soil to the far North. Quility good. Very valuable for cooking.

\section{DWARF ROCKY MOUNTAIN CHERRY.}

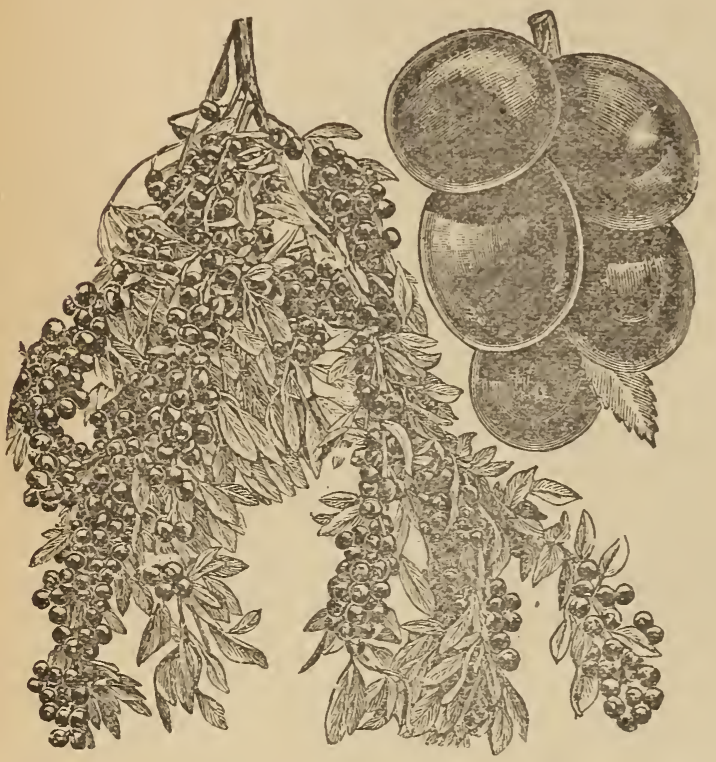

We Catalogue for the first time what we are fully persuaded is one of the finest Fruits that has ever been offered in the Northwest. We have taken great pains to study this Fruit, its habits, quality, hardiness, ete. We have made inquiries of many who have grown it, and all agree that it is a most valuable Fruit.

The originator speaks of it as follows:- "It is the most produetive fruit of which I have any knowledge. I have picked eighty cherries off a branch twelve inches long. The fruit is jet black when ripe, and in size arerages somewhat larger than the English Morello, the season of ripening being after all others are gone. In flavor, it is akin to the sweet cherries. It has the best system of roots of any shrub or tree I have ever planted, which accounts for the wonderful productiveness of plants at such an early age. It bears every year and is as prolific as a currant bush. Grows to a height of four feet, and has never been affeeted by insects, black-knot or other disease. Valuable for pies, sauce or for market purposes. It makes a handsome flowering bush, with its mass of pure white flowers."

$\begin{array}{rrr}\text { SIZE } & \text { EACH } & 10 \\ 24 \text { to } 30 \text { inches, } & 850 & \$ 450 \\ 15 \text { to } 20 \text { inches, } & 40 & 350 \\ 8 \text { to } 13 \text { inches, } & 30 & 250\end{array}$
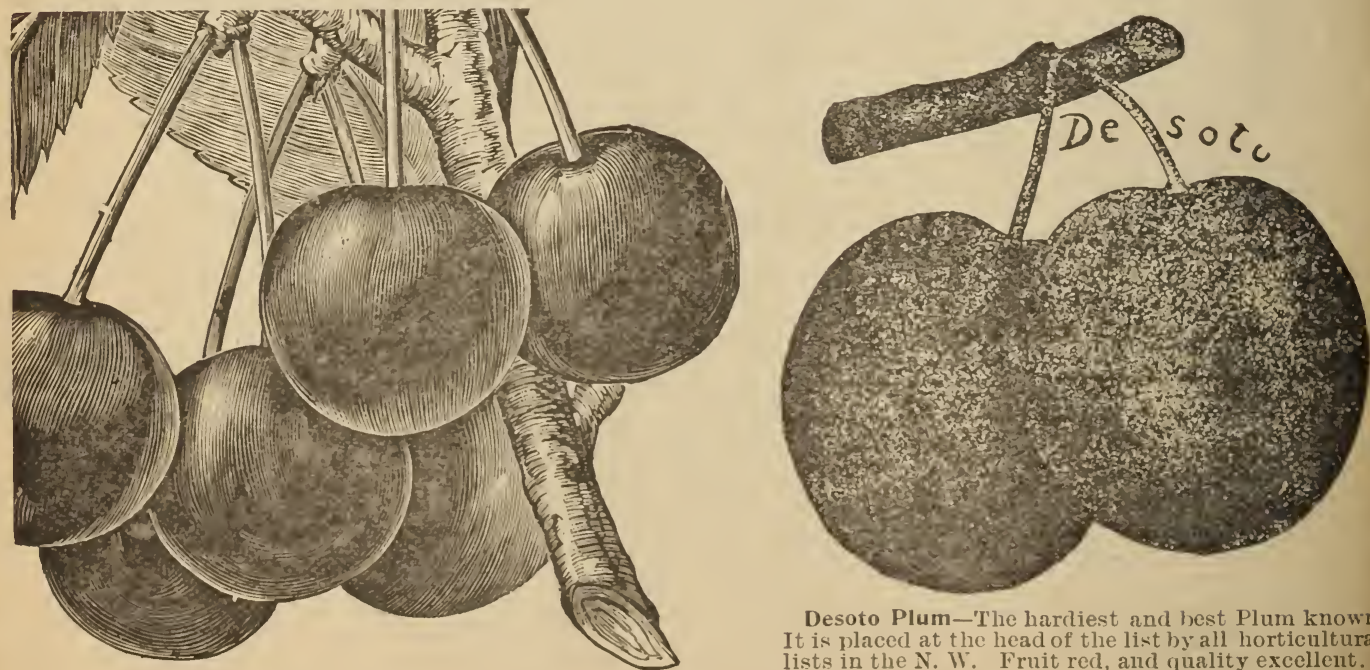

Desoto Plum-The hardiest and hest Plum known. It is placed at the head of the list by all horticulturalists in the N. W. Fruit red, and quality excellent.

The Wragg Cherry is one of the most bromising novelties in the fruit line. It is a sturdy grower, and immense bearer of large, handsome. dark colored fruit. Is one of the VERY HARDIEST eherries, and is espeeially desirable in the North. 


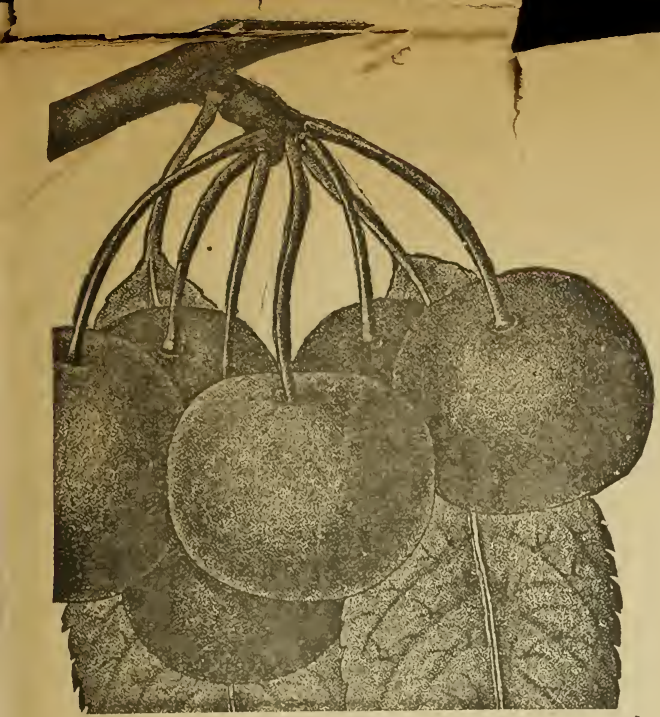

Ostnem-One of the hardiest of Cherries. Brough from the nurseries of Dr. Regal, of St. Petersburg Russia. Fruit large, flesh liver-colored, tender, juicy and sub-acid.

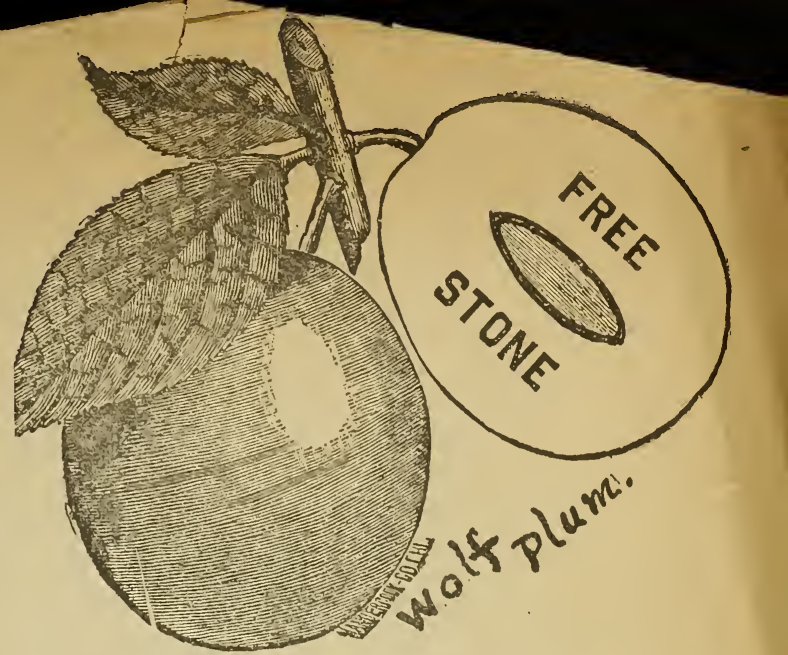

The fruit is large size, deep red, having very small pit, which separates readily from the flesli. Very rich to the taste, with none of the wild flavor perceptible in the Wild Goose. We offer a nice stock of this Plum for this season.

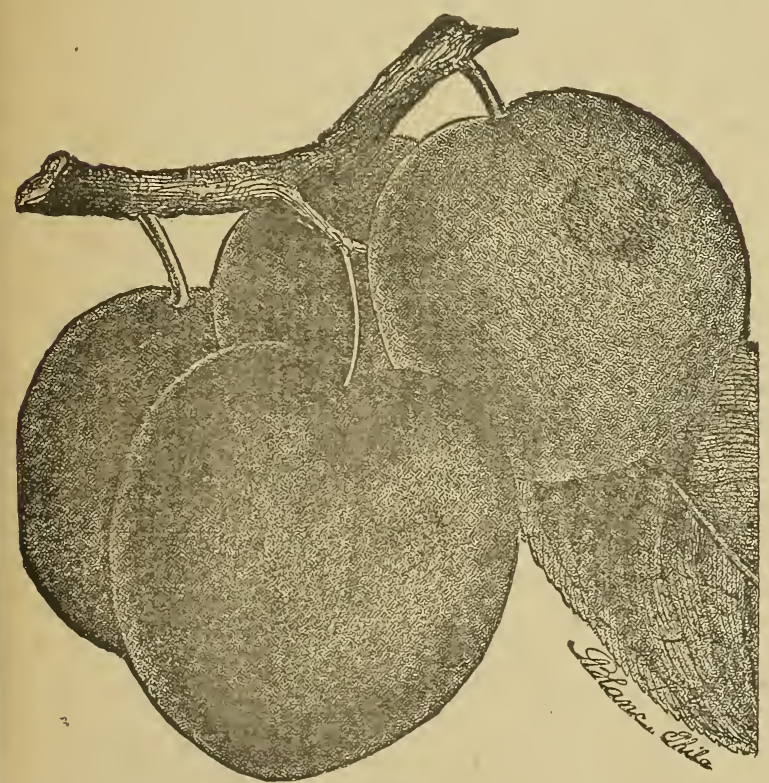

Hawkeye-Verr large: color light mottled red, super or quality firm, carries well to market. Tree hardy, thrifty, annual bearer.

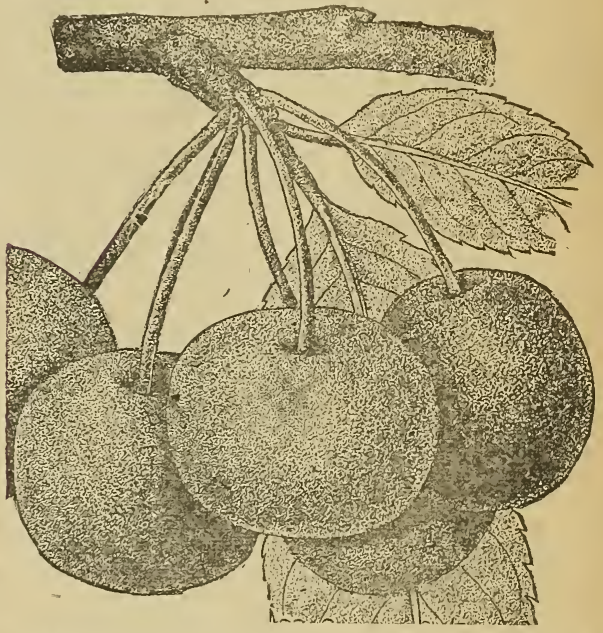

Early Richmond-Nedium size, dark red, melting juiey, sprightly, acid flavor. This is one of the most valuable and popular of the Acid Cherries, and is unsurpassed for cooking purposes, and is exceedingly productive. Free. First of June.

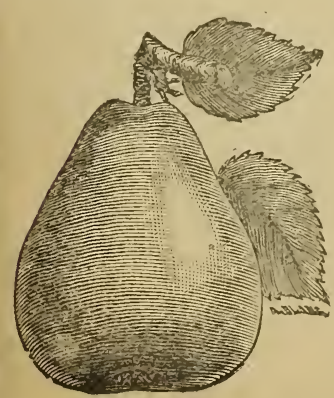

ROOT: GRAFTS.

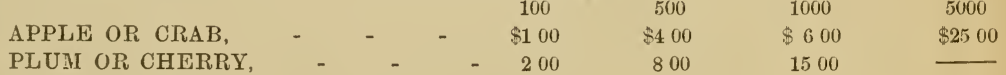

We cannot accept orders for Root Grafts later than March 20th, as our grafting will be completed by that date. Grafts should be plantedïjist as early as possihle. 


\section{JAPAN PLUMS.}

These Plums hare come to us from Japan-but are supposed to be native of Northwest China where the soil and climatic influence are similar to ours. Five or six of these varieties have been tested here in Iowa. Ther have and tested here at Sioux City for five rears, and have come through the winters in good condition, and this without any brotection. Fruit is one third larger than our native varieties, and quality of truit much superior; in fact equal to eur European varieties. Come into bearing early. Don't fall to try some of these Plums.

\begin{tabular}{|c|c|c|}
\hline $\begin{array}{l}2 \text { year } \\
3 \text { year }\end{array}$ & 4 to $5 \mathrm{ft}$. & $\begin{array}{l}\text { EACH. } \\
35 \mathrm{cts} \text {. } \\
40 \mathrm{cts}\end{array}$ \\
\hline
\end{tabular}
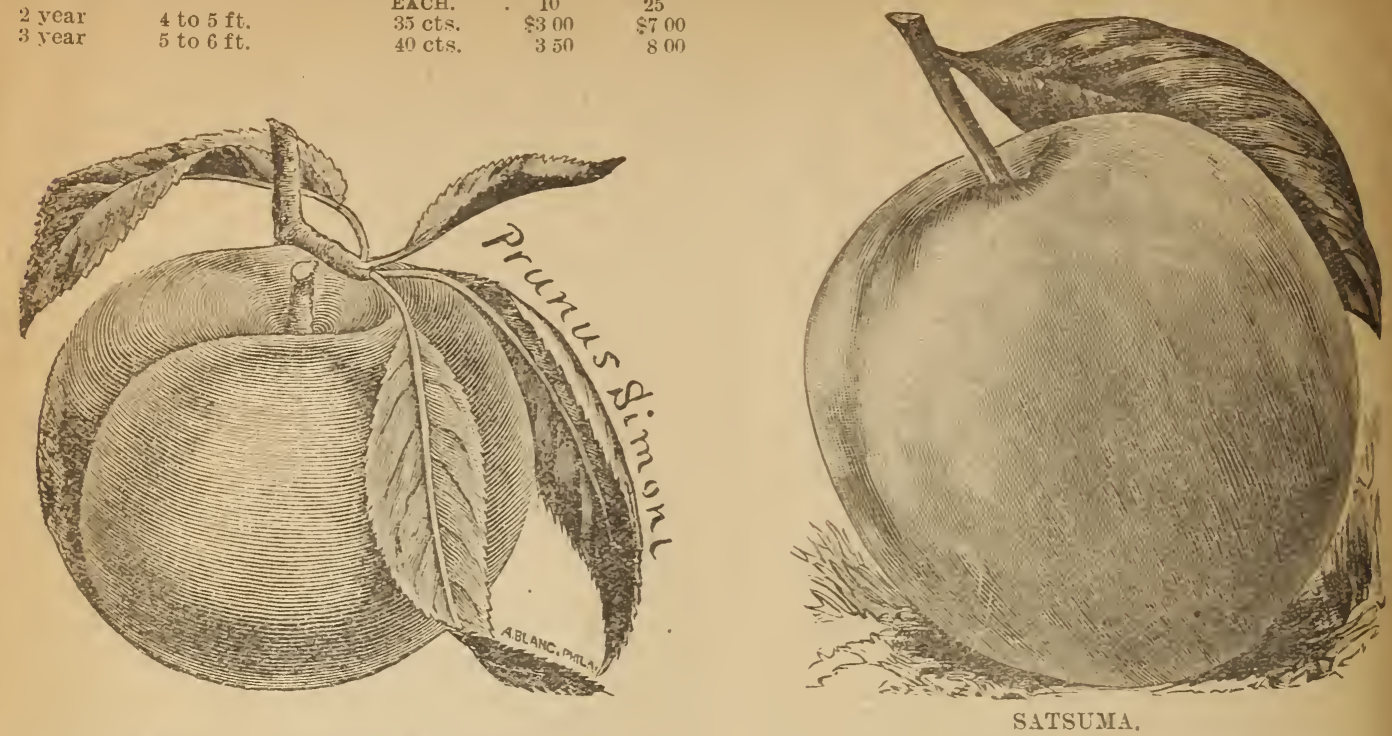

VARIETIES OF JAPAN PLUMS-Simons Plum-(Also called Prunus Simoni.) The leaves and bark look like the peach while the fruit resembles an apricot. It is a perfectly hards tree from Northern China. Has a pecular aromtic flavor not tound in any other Plum. Verr desirable both for fruit and as an ornamental tree. Abundance-Tree a strong and haudsome grower, thrifty and hardy, commences bearing young, and annually produces a large srop of showey fruit in the greatest profusion. Large, red, Hewh orange yellow, sweet, melting, juicy, and of most excellent quality. Burbank-Another exceedingly valuable sort that is proving a bonanza to all planters. A very vigorous urower, usully producing a crop second rear after transplanting. Large clear cherry recl, flesh 3 deep rellow, verv sweet, with a pecular and rery agreeable flavor, hardy, one of the best. Satsuma-Large, color purple and red with blue bloom, flesh firm, juicy, dark red or blood color, fine quality, pit very small. Hardy and vigorous grower.

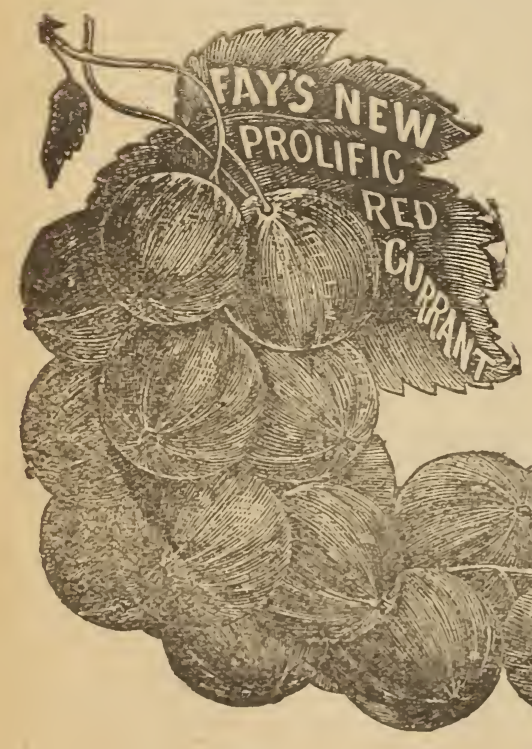

\section{SMALL FRUIT DEPARTMENT.}

There is nothing that gives greater returns and more satisfaction than small fruits, and every family owning land, from a lot to a farm. should have a "patch of small fruit.s." It is a known fact that the climate and soil in Northwest Iowa produce the strongest and hardiest of small fruits. This is recognized by horticult uralists in the east and south, and many of them are either propagating or buving their small fruits from this section. It is undeniable that all kinds of small truits, propagated here, are more vigorous, productive and hardy. than those of the east or south.

Fay's Prolific-Decidedly one of the hest Currants in cultiration. Has been widely planterl aud given general satisfaction. It is a strong grower, wonderfully prolitic, and hears, early Fruit large, bight red, and of good Havor, and very uniform in size. It is THE berry tor market, or home gardens, and you caunot afiorl to om it it from your list.

\section{BLACKBERRIES-Snyder-The harlicst} Stone's Hardy:

FASPBERRIES-Red-Cuthl) rt, or Turner.

Black-Gregg, Ohio. Marliborn, Souhegan, Tyler.

Crimson-Shaffer's Colnssal.

Yellow-Caroline or frolden (ineen,

DEWBERRY-Bartel-see description,

fOOSEBERRIFS-Houghton, 1 rr. No. 1

$$
2 \text { ir. No. } 1 \text {, }
$$

Downing, 1 yr.,

$$
2 \text { ir., }
$$

\begin{tabular}{|c|c|c|}
\hline 12 & & 25 \\
\hline 30 & $\$$ & 50 \\
\hline 411 & & 71 \\
\hline 30 & & .ill \\
\hline 411 & & 71) \\
\hline (ii) & & 1 (H) \\
\hline 511 & & (H) \\
\hline 411 & & 7.5 \\
\hline 51) & & $1 \mathrm{~cm}$ \\
\hline 7.5 & & 125 \\
\hline 30 & & fin \\
\hline 160 & & 200 \\
\hline 125 & & 50 \\
\hline
\end{tabular}

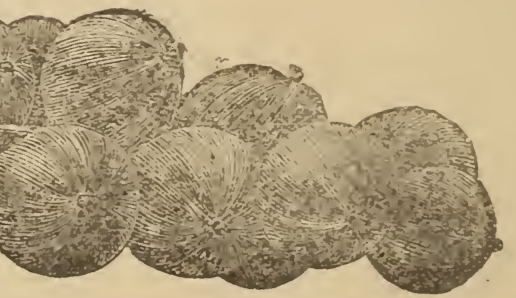


CURRANTS-Red or White, 1 yr. No. 1 ,

$$
\text { “ } 1 \text { yr. No. 2, }
$$

Fay's-1 yr. No. 1, (Genuine

Crandall-1 yr. No. 1, each, 25c,

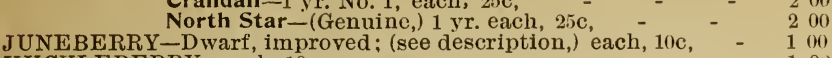

HUCKLEBERRY-each, 10c

SAND CHERRY -2 yr. 2 to $3 \mathrm{ft}$, each, $15 \mathrm{c}$

BUFFALO BERRY-15 to 20 inches, each, $25 \mathrm{c}$.

\section{ROOTS.}

ASPARAGUS-Columbian Mammoth, white, RHUBARB

Conover's Colossal or Palmetto,

HORSE RADISH,

Every garden should have a large bed of Asparagus, Rhubarb and Horse Radish. They always grow, never freeze, the first to come in the spring, and require but little care; and last for a life time. The soil should be made as rich as possible.

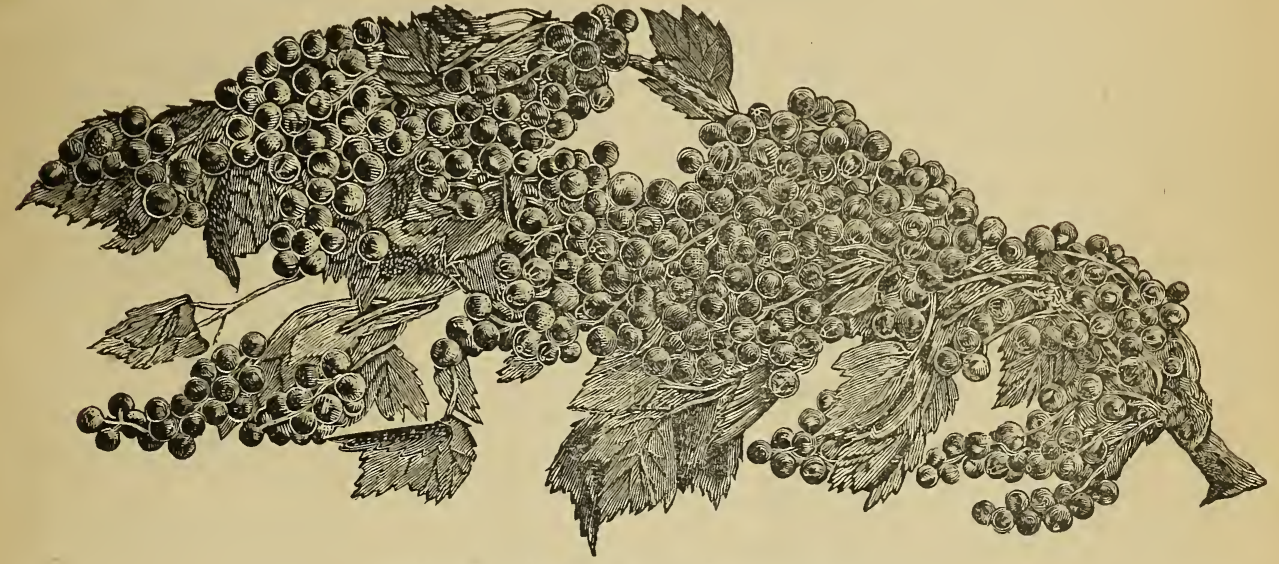

THE NORTH STAR CURRANT

is distinctly Ameriean. It is propagated in the extreme cold climate of Minnesota, where it has been tested in every conceivable way. The fruit is very large, uniform in size, of a bright red color, larger than the Red Dutch or Victoria, and rivalling the Cherry Currant, while each bush will yield double the quantity of fruit. It is less acid, much sweeter and more agreeable to eat out of hand or for table use. 'The bunches are from four to six inches long, densely packed with fruit, involving only half the labor in picking the crop. The berries cling to the branches long after the fruit is ripe, and do not shell or drop off. This habit lengthens the season of this Currant from four to six weeks. It is an early and prolific bearer. prdoucing twenty-five per cent. more fruit than the common sorts. It is never affected by borers or insect enemies.

The North Star has a bright, healthy foliage, which is retained very late in the fall, thus aiding to develop the strongest possible fruit buds. Its strong, rapid growth makes it particularly desirable for cultivation in trae form, as it requires but little pruning. Is the most desirable variety known for propagation as a "True Currant." It is perfcctly hardy, and will grow 11 any climate.

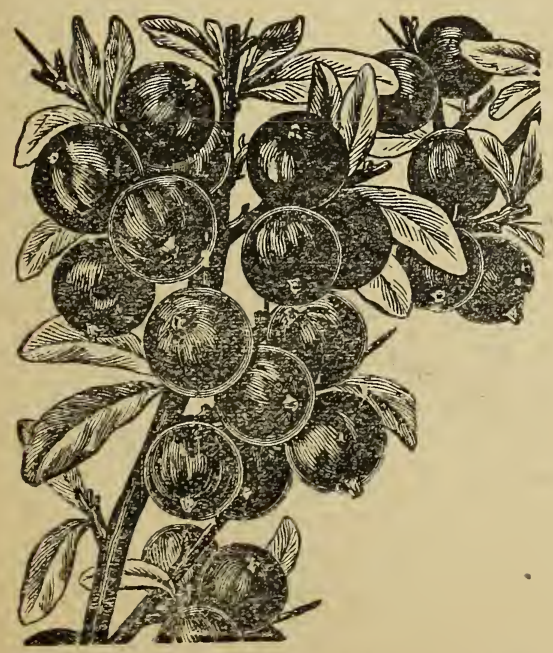

Buffalo Berry-Fruit resembles small currants, but is of richer taste, and literally covers the twigs and branches. If not gathered will remain on plants through the winter. Esteemed for pies, tarts, preserves, jellies, etc. A constant and prolific bearer, entirely hardy in all sections. and will thrive anywhere. A tree-like shrub of compact habit, well worth cultivating for ornamental purposes alone.

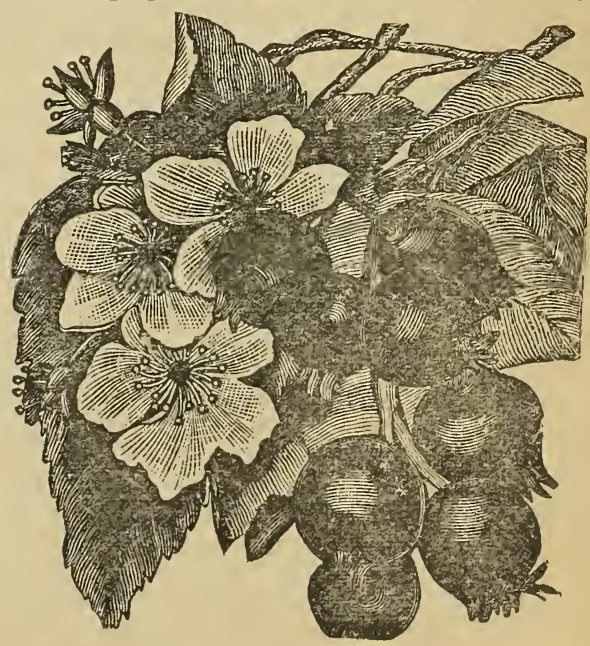

June Berry-IMPROved DwARF-A good substitute for the large or Swamp Huckleberry or Whortleberry, which it resembles. The fruit is borne in clusters, reddish-pruple in color, changing to bluish-black. In flavor it is of a mild, rich sub-acid; excellent as a dessert fruit or canned It is extremely hardy. The blossoms are quite large and composed of fine white petals, which, with its bright, glossy, dark green foliage.renders it one of the handsomest of ornamental shrubs. 


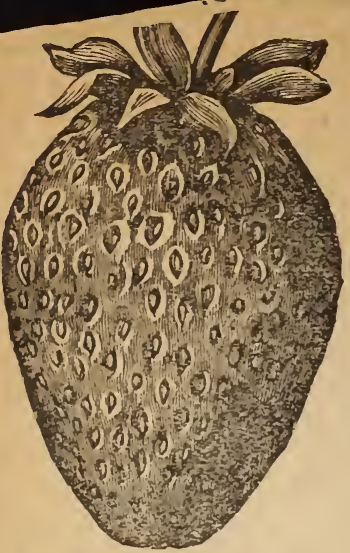

Parker Earle-Undoubtedly the hest new variety offered for ten years. Very vigorous, remarkal
productive. Stands drouth well.

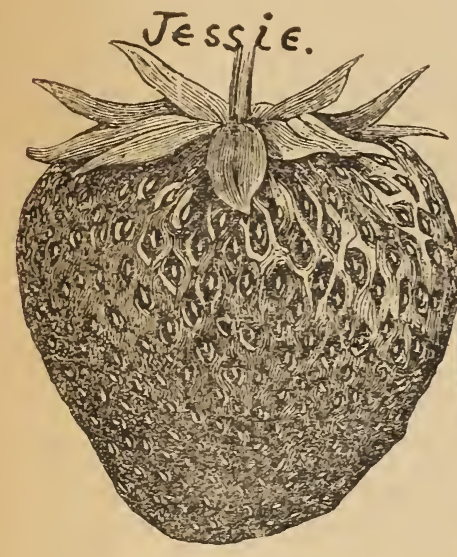

Jessie-The plant is very vigorous and healthy and a strong grower, resembling the Sharpless. The fruit is large, and holds its size well until general planting.

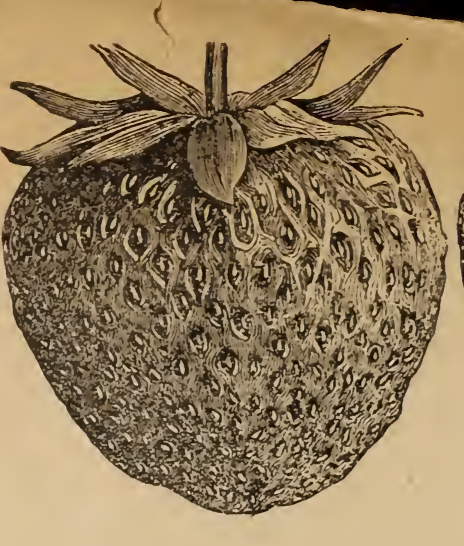

Warfield (No, 2)-P-A varie' $\mathrm{T}$ that is verclikely to supercede the Crescent, which it rivals in yifld, and excels in size, beauty and firmness. Plant is a vigorous grower of bright, healthy foliage.

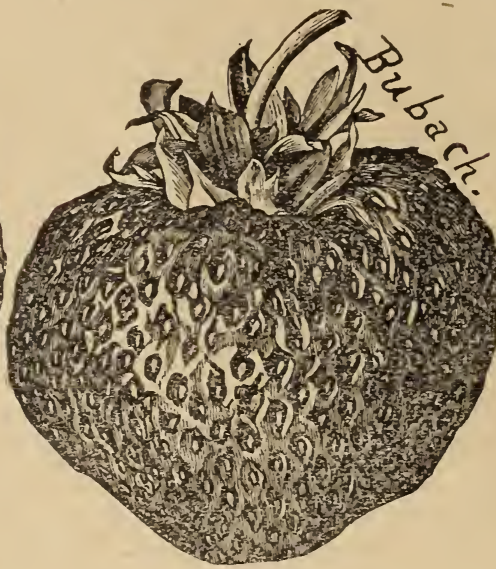

Bubach-(No. 5)-P. This berry combines great and uniform size, fine color, with unsurpassed productiveness and good quality
ef fruit. The leaves are verr large, and the hottest sun does not appear to affect them. Carries every blossom to a perfect berry. In vigor of plant and yicld of fruit it
derful, even under careless culture.
Beder Wood-By some considered the ery best early herry. Immensely productive, healthy grower. Fruit large bright red, excellent quality. For near the most satisfactorr.

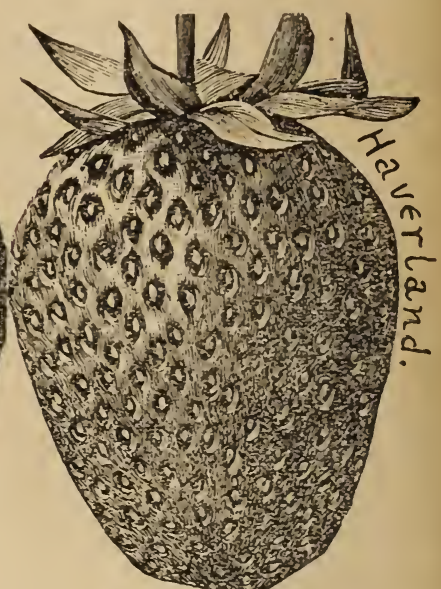

Haverland-P. Plants are very large, vigorous, and ripen their fruit venly and early, holding on through the season. Fine in shape, very arge, excellent flaror, and bright

$$
\text { ran }
$$

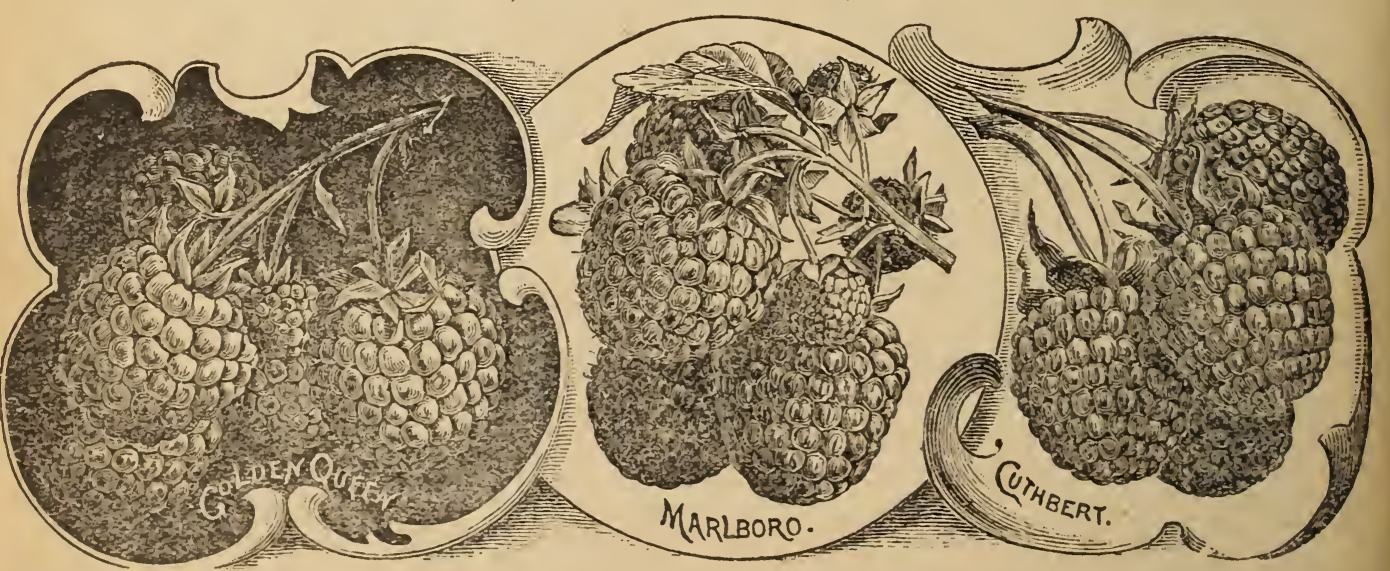

Golden Queen-A beautiful large golden vellow berry, seedling of the Cuthbert. Beauty, qualit $y$ and adaptability, succeding in all secgrowth, wonderfully productive,
Marlboro-Has proved to be one of the hardest, earliest and one of the brighter red in color, firm and hardy: Fruit very large and rery productive. The largest early Red Raspberry yet introduced.
Cuthbert-A remarkably hardy variety stands the Northern winters and Southern summers equal to any. Berries very large. crimson, and so firm ther can be shipped dition. 
(in have nerer been so cheap, nor of better quality.

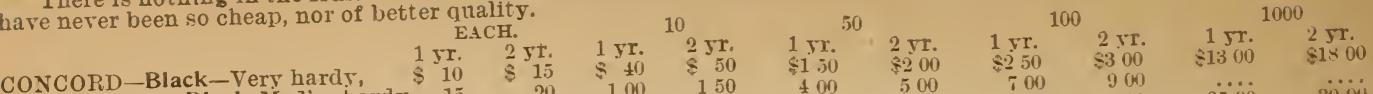

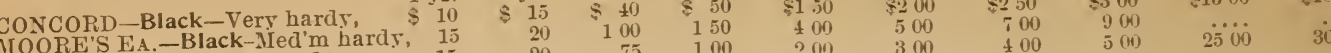
WVRDE - Black-Very hards, 15

W

JANESVILLE-Black-

MAPTHA-White-Hardy,

POCKLINGTON-Golden,

ELTIRA-White-Hardy.

BRIGHTON-Red-Hardy

NIAGARA-White-Hardy,

\begin{tabular}{rrr} 
& \multicolumn{2}{c}{10} \\
1 yr. & 2 yr. \\
5 & 40 & 850 \\
100 & 150 \\
75 & 100 \\
100 & 125 \\
100 & 150 \\
7.5 & 100 \\
100 & 125 \\
100 & 125 \\
100 & 125 \\
75 & 160
\end{tabular}

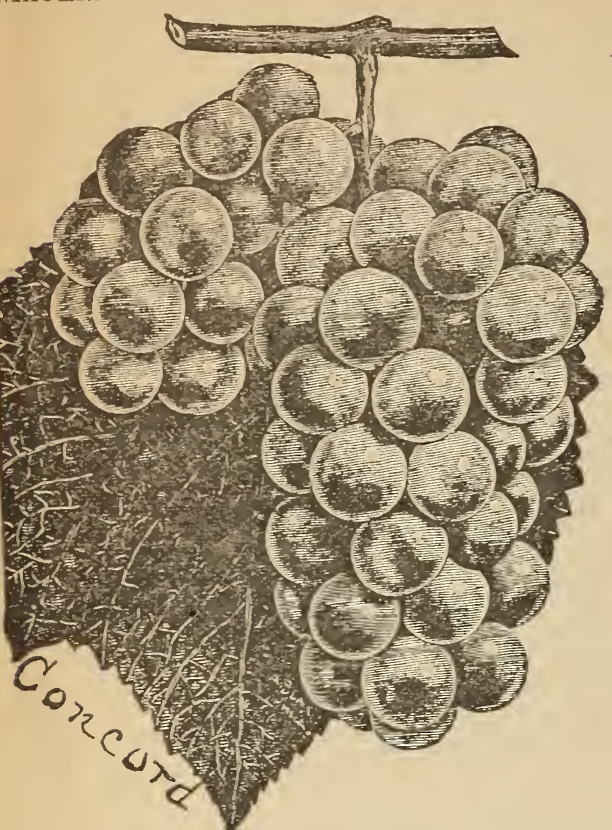

Concord-Bunches large, berries large, round; skin thick, and corered with bloom; flesh juicr sweet. thick, and the most popular of all our native sorts.

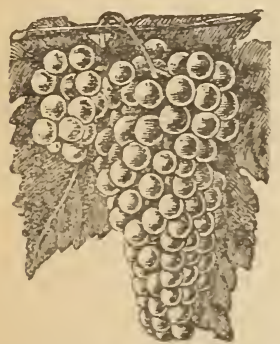

Niagara-This is the best White Grape today. Extraordinary vigorous grower free from diseases, perfectly hardy, bunches large and beautiful, quality good. Ripens five to eight days before the Concord

BULBS FOR SPRING PLANTING.

CALADIUIS-Esculentum,

CALADIUMS-Esculentum, -

GLAIIOLI-Red shades mixed, V'hite and light mixed, TUBETOSES-Double,
Pearl,

DAHLIA-Assorted colors,

PEONIES-Red or White,
Brighton-New, dark red. Ripens with, or before Delaware. Bunch large, long and shouldered, berries medium, skin thin, flesh tender, sweet, and of best mality. Vine vigorous and fairly productive. A valuable and desirable grape for garden and rinerard.

Worden-A seedling of the Concor in bur and in quality. Without doubt the hardy and healthy. See price in list.

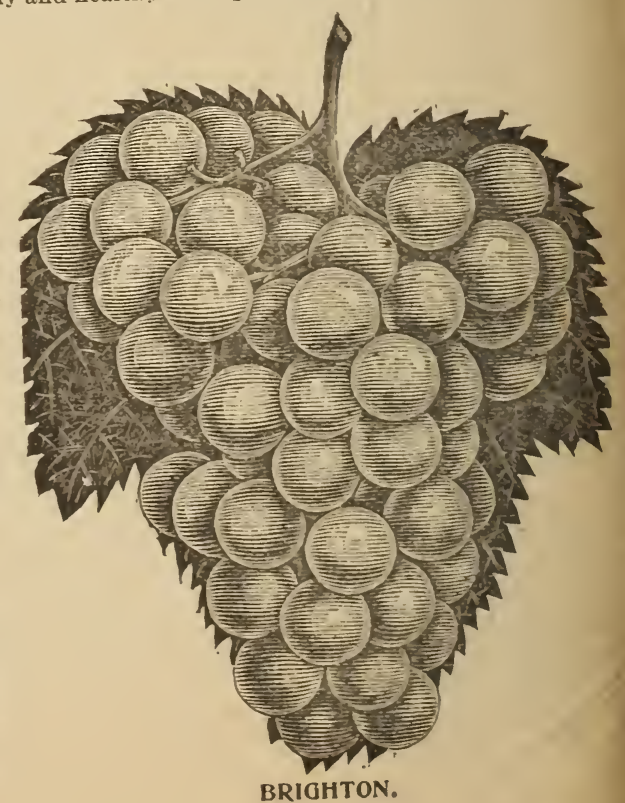


We call your attention to the great superiority of the Nursery grown seedling over the river pulled. Grown in un rich soil, receiving thorough cultivation, the roots are twice as large, and have many more rootlets. River pulled trees are pulled up, stripping off what few rootlets there may be, while the Nursery grown trees, being taken up with a treeplow, the rootlets are left on. It is not claiming too much to say that Nursery grown trees are worth more than double the river trees. Our Seedlings are Nursery grown, except Cottonwood and Maple. We guarantee FULL CounT and HEAITHY TREES.

The length of our Seedlings does not include the roots, but is from the ground up.

\begin{tabular}{|c|c|c|}
\hline KIND. & $A G E$ & SIZE \\
\hline is & 1 yr. & $\begin{array}{l}5 \text { to } 10 \mathrm{in} . \\
7 \text { to } 14 \mathrm{in} .\end{array}$ \\
\hline “ & 2 yr. & 10 to $20 \mathrm{in}$. \\
\hline & $3 \mathrm{yr}$. & 2 to $3 \mathrm{ft}$. \\
\hline X ELDER, & $1 \mathrm{yr}$. & 5 to 8 in. \\
\hline “ & $2 \mathrm{yr}$ & 10 to $16 \mathrm{in}$. \\
\hline “" & $3 \mathrm{yr}$. & 2 to $3 \mathrm{ft}$. \\
\hline & $1 \mathrm{yr}$. & 6 to 8 in. \\
\hline TTONWWOOD, & $1 \mathrm{yr}$. & 10 to $14 i n$. \\
\hline “ & $\begin{array}{l}1 \mathrm{yr} . \\
2 \mathrm{yr} .\end{array}$ & $\begin{array}{l}14 \text { to } 18 \text { in. } \\
18 \text { to } 24 \text { in. }\end{array}$ \\
\hline NUTT & $3 \mathrm{yr}$. & 2 to $3 \mathrm{ft}$. \\
\hline TTERWO & $1 \mathrm{yr}$. & 10 to $18 i n$. \\
\hline UST-H & $1 \mathrm{yr}$. & 6 to $12 \mathrm{in}$. \\
\hline Black, & $1 \mathrm{yr}$. & 10 to $20 \mathrm{in}$. \\
\hline
\end{tabular}

\begin{tabular}{|c|c|}
\hline 100 & 1000 \\
\hline$\$ 40$ & $\$ 150$ \\
\hline 50 & $\begin{array}{lll}2 & 25 \\
3 & 50\end{array}$ \\
\hline $\begin{array}{l}125 \\
\end{array}$ & 800 \\
\hline 40 & 125 \\
\hline 50 & 225 \\
\hline 60 & 350 \\
\hline 125 & 800 \\
\hline 40 & 175 \\
\hline 50 & 225 \\
\hline 30 & 150 \\
\hline $\begin{array}{l}40 \\
50\end{array}$ & $\begin{array}{l}175 \\
200\end{array}$ \\
\hline 100 & 400 \\
\hline 100 & 700 \\
\hline 125 & 900 \\
\hline 75 & 400 \\
\hline 75 & 40 \\
\hline 40 & $\begin{array}{lll}2 & 00 \\
3 & 00\end{array}$ \\
\hline $\begin{array}{l}50 \\
50\end{array}$ & 30 \\
\hline 75 & \\
\hline 100 & 00 \\
\hline
\end{tabular}

$\begin{array}{rl}5000 \\ \$ 7 & 00 \\ 11 & 00 \\ 15 & 00 \\ \ldots & 0 \\ 6 & 00 \\ 10 & 00 \\ 15 & 00 \\ \ldots & \ldots \\ 8 & 00 \\ 10 & 00 \\ 6 & 00 \\ 8 & 00 \\ 9 & 00 \\ 20 & 00 \\ 30 & 00 \\ 73 & 00 \\ 18 & 00 \\ 7 & 00 \\ 73 & 0 . \\ 14 & 00 \\ 20 & 00 \\ \ldots \ldots & \end{array}$

$10000 \quad 15000$

$\$ 1300 \$ \$ 1800$

$\begin{array}{lllll}1100 & 2100 & 3000\end{array}$

$600 \quad$ 1000 $\dddot{0} 000$

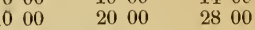

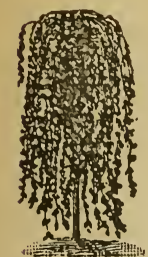

WILLOW CUTTINGS, Grey, IIULBERRY-Russian $1 \mathrm{yr}$. 6 to $12 \mathrm{in}$

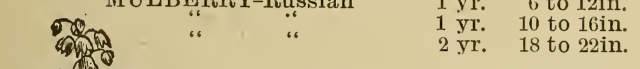

ORNAMENTAL TREES.

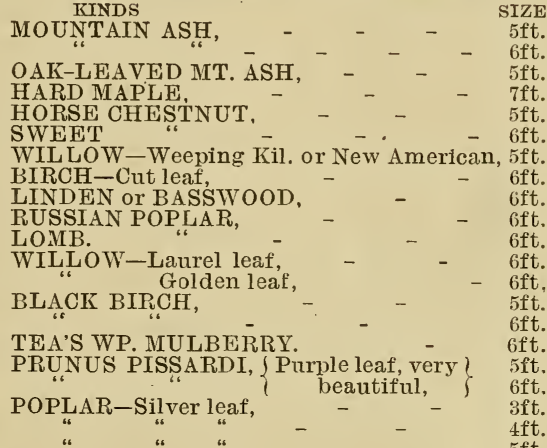

$\begin{aligned} & \\ & \text { EACH } 30 \\ & \$ 40 \\ & 45 \\ & 45 \\ & 35 \\ & 50 \\ & 50 \\ & 50 \\ & 60 \\ & 35 \\ & 35 \\ & 35 \\ & 50 \\ & 50 \\ & 40 \\ & 50 \\ & 150 \\ & 30 \\ & 40 \\ & 15 \\ & 20 \\ & 25\end{aligned}$

10 .

$\cdots+\cdots$

iii 00

$1600 \quad 2100$

-........

$+\cdots \cdots$

(n......

$\cdots \cdots+\cdots$

...........

$\cdots \cdots$

$\cdots \cdots+\cdots$

\section{SHADE TREES!! SHADE TREES!!! \\ SHADE TREES!! SHADE TREES!!}

YUCCA.

\begin{tabular}{|c|c|c|}
\hline 5 & & 10 \\
\hline$\$ 125$ & & $\$ 20$ \\
\hline 150 & & 27 \\
\hline 200 & & 2 \\
\hline $\begin{array}{ll}125 \\
\end{array}$ & & \\
\hline $\begin{array}{ll}2 & 25 \\
2 & 04\end{array}$ & & $\begin{array}{l}40 \\
40\end{array}$ \\
\hline $\begin{array}{ll}2 & 00 \\
2 & 25\end{array}$ & & $\begin{array}{l}40 \\
4\end{array}$ \\
\hline 300 & & 50 \\
\hline 125 & & \\
\hline & & \\
\hline 125 & & 20 \\
\hline $\begin{array}{l}200 \\
200 \\
2\end{array}$ & & \\
\hline $\begin{array}{ll}2 & 00 \\
1 & 50\end{array}$ & & \\
\hline 200 & & \\
\hline 0 & & \\
\hline & & \\
\hline & & \\
\hline & & 1 \\
\hline & & 1 \\
\hline
\end{tabular}

We have, without doubt the finest line of Shade Trees in the West. We have them in large quantities, too. They are all Nursery Grown, have been thoroughly cultivated, carefully pruned, are straight, smooth and well branched, and have large roots. They are all Transplanted Stock. We invite correspondence with Park, Cemetery and Street Committees, and all others wanting fine Shade Trees.

KIND

ASH,

LOCUST-Honey,

CATALPA, or

WALNUT.

$\left\{\begin{array}{l}\text { sIzE. } \\ 3 \mathrm{ft} . \\ 4 \mathrm{ft} . \\ 5 \mathrm{ft} . \\ 6 \mathrm{ft} . \\ 7 \mathrm{ft} . \\ 8 \mathrm{ft} . \\ 9 \mathrm{ft} .\end{array}\right.$

$\begin{array}{rr}10 & 100 \\ 40 & \$ 300 \\ 50 & 400 \\ 60 & 500 \\ 75 & 600 \\ 100 & 800 \\ 125 & 1000 \\ 175 & 1600\end{array}$

\begin{aligned} 500 & \multicolumn{1}{c}{ KINTS } \\ $\$ 1200 &$ BOX ELDER, \\ 1800 & ELM, \\ 2200 & MULBERRY, \\ 2500 & SYCAMORE, \\ 3600 & LOCUST-Black, \\ $\cdots \cdots &$ or \end{aligned}

$\left\{\begin{array}{r}\text { SIZE } \\ 3 \mathrm{ft} . \\ 4 \mathrm{ft} . \\ 5 \mathrm{ft} . \\ 6 \mathrm{ft} . \\ 7 \mathrm{ft} . \\ 8 \mathrm{ft} . \\ 9 \mathrm{ft} .\end{array}\right.$

$\begin{array}{rrr} & 10 & 100 \\ \$ 50 & \$ 350 \\ 60 & 500 \\ 75 & 600 \\ 90 & 750 \\ 125 & 1000 \\ 200 & 1500 \\ 300 & 2500\end{array}$

$\$ 1300$

2000

2000

3000

.....

ROSES, SHRUBS, VINES, ETC.

ROSES-Hybrid, Perpetual, Climbing, Moss-leading varietios,

Our lioses are strong, two vears old, and have le sn grown out of doors one season, All the above Roses are hardy, but a little loose covering of soil will make them bloom freer. In $\mathbf{H}$. P. Roses the followiug three are the hardiest and best bloom rrs: Gen. Jacqueminot, brilliant crimson; Paul Ney ron, deep rose; LaFrance, silvery white.

In Climbing Roses the Prairie Queen, bright rose; Seven Sisters, purplish crimson; Baltimore Bell, pale blush.

In Moss Roses, Red Moss, White Moss and Princess Adolaide. Summer Roses-Harrison or Persian Yellow.

SHRUBS-Showballs, Lylac, Syringa, FI. Almond, Yucca,

FI. Currant, Lylac, Persian or white; Hydrangia, Japan Quince,

$\begin{array}{rr}\mathrm{EACH} & 5 \\ \$ 25 & \$ 110 \\ 25 & 110 \\ 30 & 1125\end{array}$

$\$ 200$

200

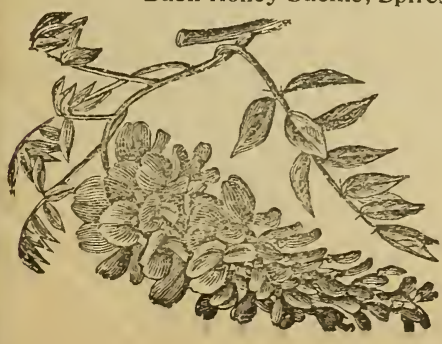

Our Shrubs are very fine, and will run from 20 inches to 3 feet.

VINES-Clematis Jackmani, Strong plants, - $60 \quad 250$

W'dbine, Wistaria, Honey Suckle, Scariet, Chinese, $25 \quad 100$

i 75

Wistaria-One of the most elegant and rapid growing of climbing plants; attains an immense size, growing at the rate of 15 or 20 feet in a season. Has long, pendulous clusters of pale blue flowers in May and June, and in autumn. 

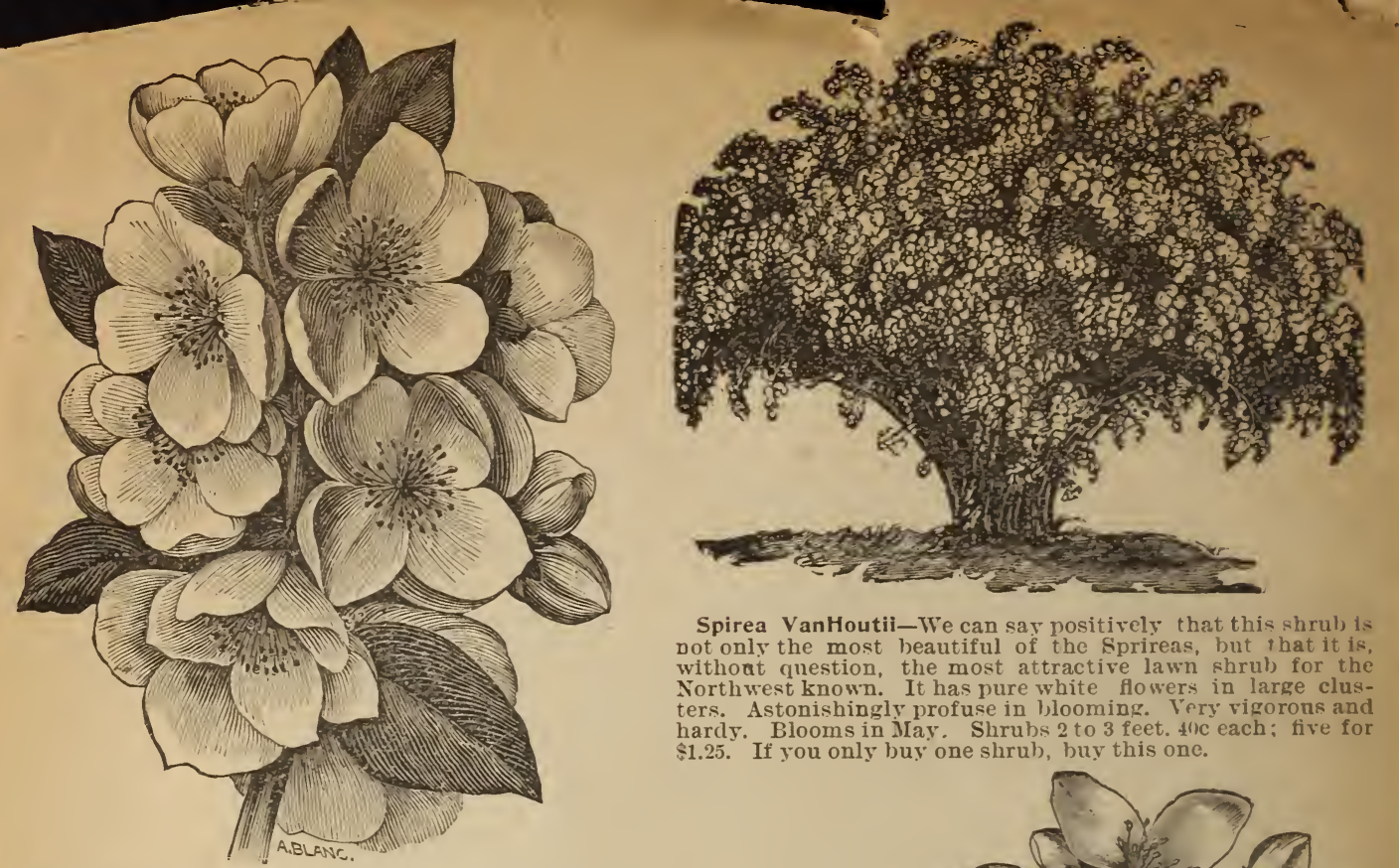

Spirea VanHoutii-We can say positively that this shrub is not only the most beautiful of the Spriress, but that it is, without question, the most attractive lawn shrub for the Northwest known. It has pure white flowers in large clusters. Astonishingly profuse in blooming. Very vigorons and

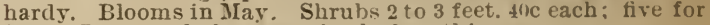
$\$ 1.25$. If you only buy one shrub, buy this one.

Japan Quince-This is one of the finest shrubs for the lawn. Needs no protection. Flowers delicate white and blush. Blooms last of April. 40c each.
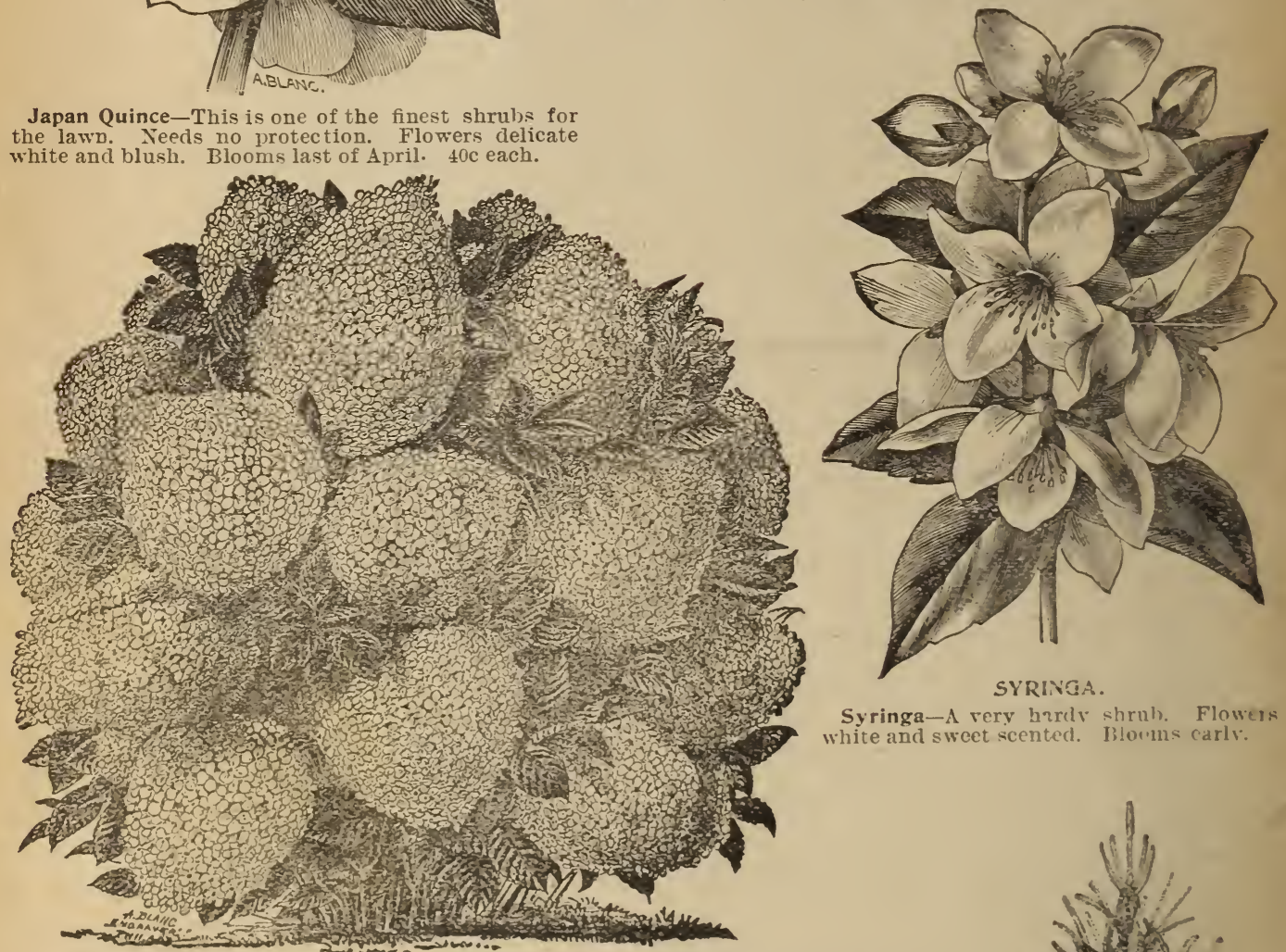

Syringa-A rery hardy shruh. Flowers white and sweet scented. IBlowims carlv:

Hydrangia Paniculata franditura-This is one of the most valuable hardy shruhs. I attains - icight of \pm or 5 fect, anl is perfectly harly in all parts of the country. The
flowers a witc, borne in immense pyramiclal panicalcs. It commences floweriug in July anu contimes until
EVERGREENS.

1) IOZE? 1i to 27

2) $\operatorname{ton} 2.5$

to 10 inoh 4 Sordlings. Spruce, Balam Fir.
ELACK HILLS SPRUCE, and COLORADO BLUE SPRUCE.

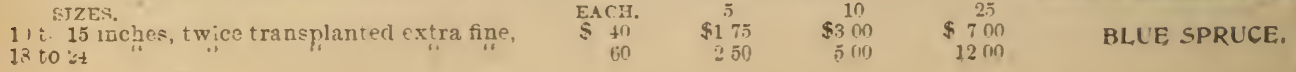

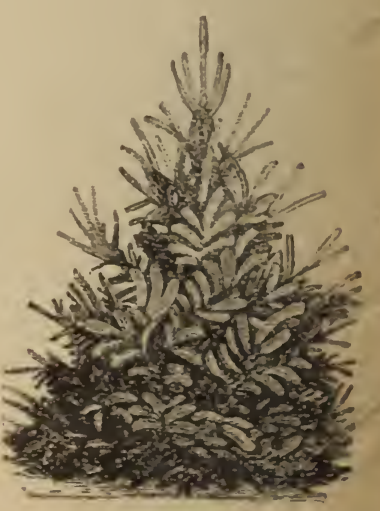

